\title{
Tilting Movements of the Japanese Islands Inferred from Cretaceous and Early Tertiary Paleomagnetic Data
}

\author{
Haruaki ITO and Katsuyasu TOKIEDA \\ Department of Physics, Faculty of Science, Shimane University, Matsue, Japan
}

(Received January 14, 1986)

\begin{abstract}
Cretaceous and early Tertiary rocks have been collected, by many workers including the present authors, from about two hundred sites in the Japanese Islands and South Korea for paleomagnetic investigations. The area mean direction of magnetization for the Oshima Peninsula and Okushiri Island of Hokkaido was $30.0^{\circ}$ in declination and $58.4^{\circ}$ in inclination. It differs distinctly from the area mean direction for granitic rocks from the Kitakami and Abukuma mountains. The area mean direction of magnetization obtained from the northern Kitakami belt was extremely westerly $\left(D=-81.1^{\circ}, I=22.3^{\circ}\right)$ and that from the southern Kitakami belt was northwesterly $\left(D=-44.4^{\circ}, I=51.7^{\circ}\right)$. The area mean from the Abukuma belt was also northwesterly $\left(D=-31.9^{\circ}, I=54.6^{\circ}\right)$. The site mean directions of magnetization for granitic rocks in the Uetsu Province were not significantly grouped in the area. In Southwest Honshu, the area mean direction of the normal samples from various kinds of Cretaceous rocks was $50.2^{\circ}$ in declination and $60.5^{\circ}$ in inclination and that of the reversed ones was $-114.8^{\circ}$ and $-55.8^{\circ}$, respectively. The normal and reversed magnetizations of early Tertiary rocks have shown similar directions to those of the Cretaceous rocks. The area mean of the normal samples was $D=37.6^{\circ}, I=52.3^{\circ}$ and that of the reversed ones was $D=-131.4^{\circ}, I=-44.8^{\circ}$, respectively. The site mean directions of magnetization for Cretaceous rocks in South Korea appear to be slightly northeasterly at each sampling site. The remarkable discrepancy between these area mean directions of magnetization is interpreted as being due to regional tilting movements which occurred in the Japanese Islands since the Cretaceous.
\end{abstract}

\section{Introduction}

Paleomagnetic directions of rocks may have been affected by various tectonic movements, such as folding, faulting or tilting, and evidences of these tectonic movements will still remain on the remanent vectors of rocks. Therefore, the paleomagnetic directions of rock masses would provide useful pieces of information about the form and timing of deformation of the rock masses followed by tectonic events.

In England, CLEGG et al. (1954) suggested, on the basis of paleomagnetic results of Triassic red sandstones, that England had rotated about $30^{\circ}$ clockwise and drifted northward since the Triassic, and they successfully explained the deflection in paleomagnetic directions. In Japan, the bending hypothesis of the Honshu Island proposed by KAWAI et al. (1961) is well known. KAWAI et al. $(1961,1962,1971)$ noticed that there was the remarkable discrepancy in declination between preTertiary rocks collected from Southwest and Northeast Japan, and they pointed out 
that it would be well interpreted by clockwise and anti-clockwise rotations of Southwest Japan and Northeast Japan. On the other hand, SASAJIMA et al. (1968) suggested that Southwest Japan had drifted northeastward from a lower latitude and rotated clockwise by about $20^{\circ}$ since the Cretaceous by using the paleomagnetic data obtained from Southwest Japan. On the contrary, a possibility of southward drifting of Southwest Japan from a higher latitude has been discussed by YASKAWA (1973, 1975). In these cases, it is assumed that the geomagnetic field has always been the same dipole field as it is now and that the geomagnetic poles since the Cretaceous were situated near the present geographic poles. Recently, investigations of rotational deformations or drifting of land masses have been reported from East and Southeast Asia by several workers (e.g., MCELHINNY, 1973; SASAJIMA et al., 1979; OTOFUJI et al., 1981; OTOFUJI and MATSUDA, 1983; ACHACHE et al., 1983).

The deviation in paleomagnetic declination from the present geomagnetic declination is usually explained by rotation about a vertical axis and that in inclination by latitudinal drift of a land mass sampled. In general, it is thought that regional tectonic movements were produced by rotations about inclined axes. However, rotation mechanisms about the inclined axes are not so simple, and such mechanisms are hard to relate to the paleomagnetic results. Two rotational movements about the vertical and horizontal axes which are well known are particular cases of rotations about the inclined axes. We assumed that regional tectonic deformations were produced by rotations about the horizontal axes from some paleomagnetic results described below.

Granitic rocks in the Oshima Peninsula and Kitakami Province have nearly the same ages according to KAWANO and UEDA (1967), but a area mean paleomagnetic direction of the Oshima Peninsula was north-easterly and that of the Kitakami region was northwesterly. The area mean directions of these two areas are obviously discordant with each other (ITO and TOKIEDA, 1974; ITO et al., 1980). On the other hand, remanent magnetizations of Cretaceous and Paleogene granitic rocks in the Uetsu Province of Northeast Honshu showed apparently different directions among individual rock masses. This result suggests that more local tectonic deformations than the Kitakami region occurred in the Uetsu region. Accordingly, as we described in previous papers (ITO and TOKIEDA, 1974; ITO et al., 1980), we supposed that there was little possibility of anti-clockwise rotation of Northeast Honshu including the southwestern part of Hokkaido and that the paleomagnetic directions of the Oshima Peninsula, Kitakami and Abukuma regions were mostly caused by regional rotational movements about the horizontal axes in each area. In this paper, a probability of tilting deformations of the Japanese Islands will be discussed from paleomagnetic data of granitic rocks which we mainly collected and also the published paleomagnetic data of igneous and sedimentary rocks in the Cretaceous and early Tertiary.

\section{Remanent Magnetization of Granitic Rocks}

The depth of emplacement of granitic intrusions is considered to be of the order of hundred or thousand meters below the original cover and overall crystallization temperatures of such intrusions appear to be usually in the range $900^{\circ}-600^{\circ} \mathrm{C}$ (e.g., BIRTH, 1962; RAGUIN, 1965). The natural remanent magnetization (NRM) of granitic 
rocks is almost the thermo-remanent magnetization acquired when they were cooled through the Curie temperature of ferromagnetic minerals contained therein. After the acquisition of remanent magnetizations, it is considered that some formations overlying the granitic rocks should have been gradually removed and consequently the granitic rocks are considered to have been uplifted to present positions of the surface.

Paleomagnetic data for granitic rocks in Japan and South Korea indicated that directions of stable component of magnetization obtained from a number of sites within a single body cluster about a mean direction of magnetization. The betweensite consistency in direction within a body has been repeatedly observed from Cretaceous and early Tertiary granitic rock masses with the stable NRM in Japan. The absence of remarkable difference in paleomagnetic directions between sampling sites within a body implies that no intensive plastic deformations which disturb the paleomagnetic directions at each site occurred in the body. The remanent vectors of granitic rocks should show no change in directions of NRM by simple vertical displacements of the blocks without rotational movements. Therefore, the betweensite consistency in NRM directions within a rock mass suggests that the mass have moved as a block for some tectonic movements after the emplacement.

On the other hand, granitic rock masses having unstable NRM or exhibiting within-site scatter in magnetic directions are frequently observed from various regions of Japan, but such paleomagnetic data have always been dropped like a hot potato. It seems to us that granitic bodies showing unstable or within-site inconsistency have undergone intensive local tectonic distortions or excessive weathering after the emplacement. Thus, paleomagnetic data of granitic rocks in the Cretaceous and early Tertiary in Japan suggest that granitic masses showing the stable magnetization and between-site consistency in directions are useful for the study of tectonic movements using paleomagnetic techniques.

\section{Geological Setting and Sampling}

Cretaceous and early Tertiary granitic rocks are widely exposed in Hokkaido, Honshu, Shikoku, Kyushu and the other small islands in Japan, and radiometric ages of their rocks have been reported by many workers (NozAwA, 1975). On the other hand, magnetic susceptibility of Japanese granitic rocks is measured on about 1200 samples by Ishihara and his co-workers (KANAYA and ISHIHARA, 1973; KANAYA, 1974; ISHIHARA, 1979; ISHIHARA et al., 1979). Magnetic susceptibility is converted to magnetite content and the amount of magnetite decreases from quartz diorite or tonalite to granite in general. According to ISHIHARA (1979), high values of magnetic susceptibility are found in granitic rocks of the Kitakami belt, San-in belt and northern Kyushu belt. The magnetic susceptibility of granitic rocks in the Abukuma belt is usually lower than that in the Kitakami belt. Most of the granitic rocks in southwestern Hokkaido, Okushiri Island and the Uetsu region have magnetically similar character to that of the Abukuma region.

\subsection{Oshima Peninsula and Okushiri Island of Hokkaido}

The area sampled is in between latitude $42^{\circ} 05^{\prime}-42^{\circ} 35^{\prime} \mathrm{N}$ and longitude $139^{\circ} 45^{\prime}-140^{\circ} 15^{\prime} \mathrm{E}$ in the Oshima Peninsula. The $\mathrm{K}-\mathrm{Ar}$ ages of the Setana and 
Imagane granodiorite masses are $111 \mathrm{Ma}$ and $124 \mathrm{Ma}$ according to KAWANO and UEDA (1966a). The K-Ar biotite ages of $114 \mathrm{Ma}$ and $133 \mathrm{Ma}$ are recently given to the Yurappu-dake granodiorite mass (IsHIDA, 1981). The $\mathrm{K}-\mathrm{Ar}$ age of a granodiorite sample taken from the west coast of the Okushiri Island is 95.8 $\pm 3.1 \mathrm{Ma}$ (SHIBATA and YAMADA, 1978). Oriented hand samples were collected from the Imagane, Setana and Yurappu-dake masses in the Oshima Peninsula and a few small granodiorite bodies in the Okushiri Island.

\subsection{Uetsu Province}

The sampling area in the Uetsu Province is in between latitude $38^{\circ} 00^{\prime}-40^{\circ} 30^{\prime} \mathrm{N}$ and longitude $139^{\circ} 35^{\prime}-140^{\circ} 50^{\prime} \mathrm{E}$. The main masses of granitic rocks sampled in this area are exposed in the Asahi highland and its vicinity, Taiheizan, Shirakami-dake and Tazawa-ko areas. We collected granitic rock samples from more than 20 sites in the area. The ages of granitic rocks sampled in this area range mainly from 100 to 55 Ma (KAWANO and UEDA, 1966a; NozAWA, 1975).

\subsection{Kitakami Province}

The Kitakami Province has been divided into six zones by petro logic and petro-chemical investigations (KATADA et al., 1971; KATADA and KANAYA, 1980). However, we conveniently divided it into two parts, northern and southern Kitakami blocks, whose divider corresponds to the Morioka-Goyozan tectonic line, because a significant difference in NRM directions of granitic rocks is found between their two blocks (ITO and TOKIEDA, 1980). Some of the granitic rocks are associated with lower Cretaceous volcanic formations and are thought, therefore, to be of relative high-level emplacement (NOZAWA, 1983). The northern part of the Kitakami mountains sampled is in between latitude $39^{\circ} 40^{\prime}-40^{\circ} 15^{\prime} \mathrm{N}$ and longitude $141^{\circ} 10^{\prime}-142^{\circ} 00^{\prime} \mathrm{E}$ and the southern part in between $38^{\circ} 15^{\prime}-39^{\circ} 30^{\prime} \mathrm{N}$ and $141^{\circ} 10^{\prime}-141^{\circ} 50^{\prime} \mathrm{E}$. The ages of granitic rocks collected fall in about 125 to $100 \mathrm{Ma}$ (KAWANO and UEDA, 1964, 1965a; NozAWA, 1975). The Kitakami granitic rocks exposed in Kinkasan Island are dated at 120 to 84 Ma by KAWANO and UEDA $(1964,1965 a)$.

\subsection{Abukuma Province}

Cretaceous granitic rocks of the Abukuma mountains are composed of two facies. The earlier facies comprises mainly quartz diorite, tonalite and granodiorite, intruding the Abukuma metamorphic rocks concordantly. The latter facies is composed mainly of granite and granodiorite, forming discordant intrusions. Both facies have nearly the same $\mathrm{K}-\mathrm{Ar}$ age of mid-Cretaceous (NOZAWA, 1983). The area sampled is in between latitude $37^{\circ} 10^{\prime}-37^{\circ} 40^{\prime} \mathrm{N}$ and longitude $140^{\circ} 35^{\prime}-141^{\circ} 00^{\prime} \mathrm{E}$ in the northern part of the Abukuma Province. The $\mathrm{K}-\mathrm{Ar}$ ages of granitic rocks sampled in this area are 100 to $90 \mathrm{Ma}$ (KAWANO and UEDA, 1965b, 1966a).

\subsection{Southwest Honshu}

Felsic intrusive and extrusive rocks are widely exposed in the Chugoku district, and granite-rhyolite association is also found in the northern Kinki region on a relatively small scale (NOZAWA, 1983). Granitic rocks in the Chugoku district are divided into two zones (MURAKAMI, 1974). The southern zone contains a large batholith associated with upper Cretaceous volcanic rocks and small bodies of quartz 
syenite are found in this batholith. The radiometric ages indicate mostly 90 to $75 \mathrm{Ma}$. The northern zone contains granitic masses of batholithic dimensions and sporadic, minor, high-level intrusive masses. They have $\mathrm{K}-\mathrm{Ar}$ ages of 65 to $40 \mathrm{Ma}$ (NOZAWA, 1983). The area sampled is widely ranging and in between latitude $33^{\circ} 50^{\prime}-36^{\circ} 55^{\prime} \mathrm{N}$ and longitude $130^{\circ} 50^{\prime}-137^{\circ} 40^{\prime} \mathrm{E}$ in the Kinki and Chugoku Provinces. More than 2000 samples were collected from granitic rocks of the Mesozoic and early Tertiary ages in Southwest Honshu. The ages of granitic rocks sampled fall in 90 to $25 \mathrm{Ma}$ (KAWANO and UEDA, 1966b).

\subsection{Northern Kyushu}

Various kinds of Cretaceous granitic rocks are widely exposed in the northern Kyushu region (mainly Fukuoka Prefecture) and they are unconformably overlain by Paleogene formations (NOZAWA, 1983). Most of their granitic rocks belong to the magnetite series, according to ISHIHARA et al. (1979). The sampling area is in between latitude $33^{\circ} 20^{\prime}-33^{\circ} 55^{\prime} \mathrm{N}$ and longitude $130^{\circ} 05^{\prime}-130^{\circ} 50^{\prime} \mathrm{E}$. The ages of samples collected are 100 to $80 \mathrm{Ma}$ (KAWANO and UEDA, 1966b; NoZAWA, 1975).

\subsection{South Korea}

Jurassic to Cretaceous granitic rocks are widely exposed in the southern part of the Korean Peninsula (LEE, 1981; Tsusue et al., 1981). The radiometric ages of granitic rocks in the Korean Peninsula are compiled by the Section of Mineralogy, GEOLOGICAL SURVEY OF KorEa (1972). We collected 128 samples from 13 sites in seven granitic bodies showing 121 to $71 \mathrm{Ma}$, according to the radiometric age map. The area sampled is in between latitude $35^{\circ} 15^{\prime}-37^{\circ} 00^{\prime} \mathrm{N}$ and longitude $127^{\circ} 35^{\prime}-$ $129^{\circ} 30^{\prime}$ E. Recently, LEE and UEDA (1977) and LEE (1980) reported the K-Ar age data of granitic rocks from the southern Gyeongsang basin. The granitic rocks in this basin mostly have the $\mathrm{K}-\mathrm{Ar}$ ages of 115 to $41 \mathrm{Ma}$.

\section{Results of Measurements}

Oriented hand samples collected have been drilled in the laboratory and core samples with $2.3 \mathrm{~cm}$ in diameter and $2.3 \mathrm{~cm}$ high have been made. All core samples were measured with a spinner magnetometer and examined by alternating field demagnetization of peak field of 10 to $120 \mathrm{mT}$. Results of measurements of the NRM of granitic rocks which we examined and the paleomagnetic data used in this paper are listed in Tables 1 to 8 . Figures 1 and 2 show the site mean directions of NRM at each sampling site from the seven provinces in Japan and South Korea.

\subsection{Oshima Peninsula and Okushiri Island}

The Cretaceous granitic rocks in the Oshima Peninsula and Okushiri Island of Hokkaido are normally magnetized and directions of NRM were found to be almost northeasterly as shown in Fig. 1 and Table 1 (ITO and TOKIEDA, 1974; NoTSU and ITO, 1982). Site mean directions obtained from these two regions are distributed in the range from slightly northeasterly to easterly (Fig. 1).

\subsection{Uetsu Province}

A few granitic bodies which have negative inclination were found in this region 


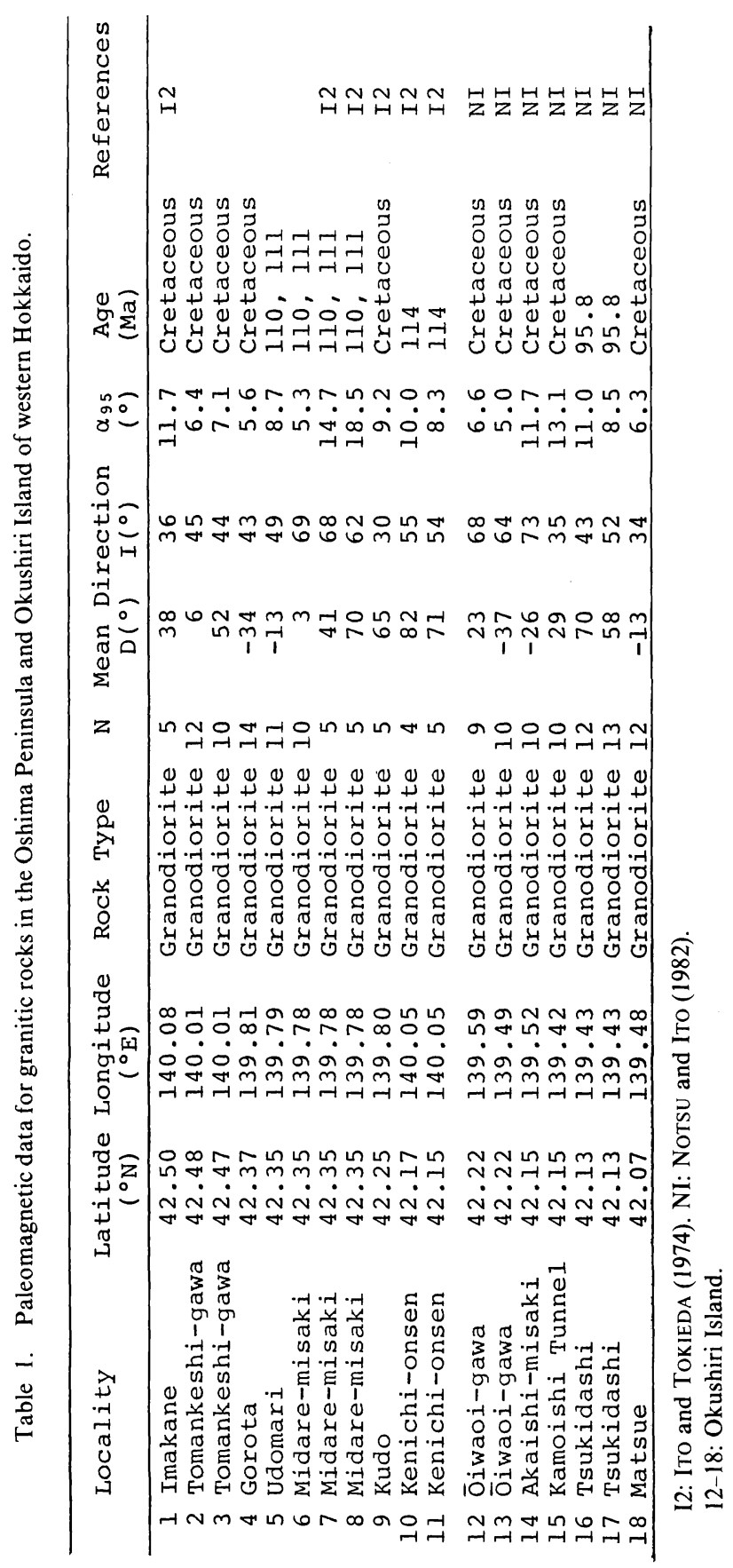




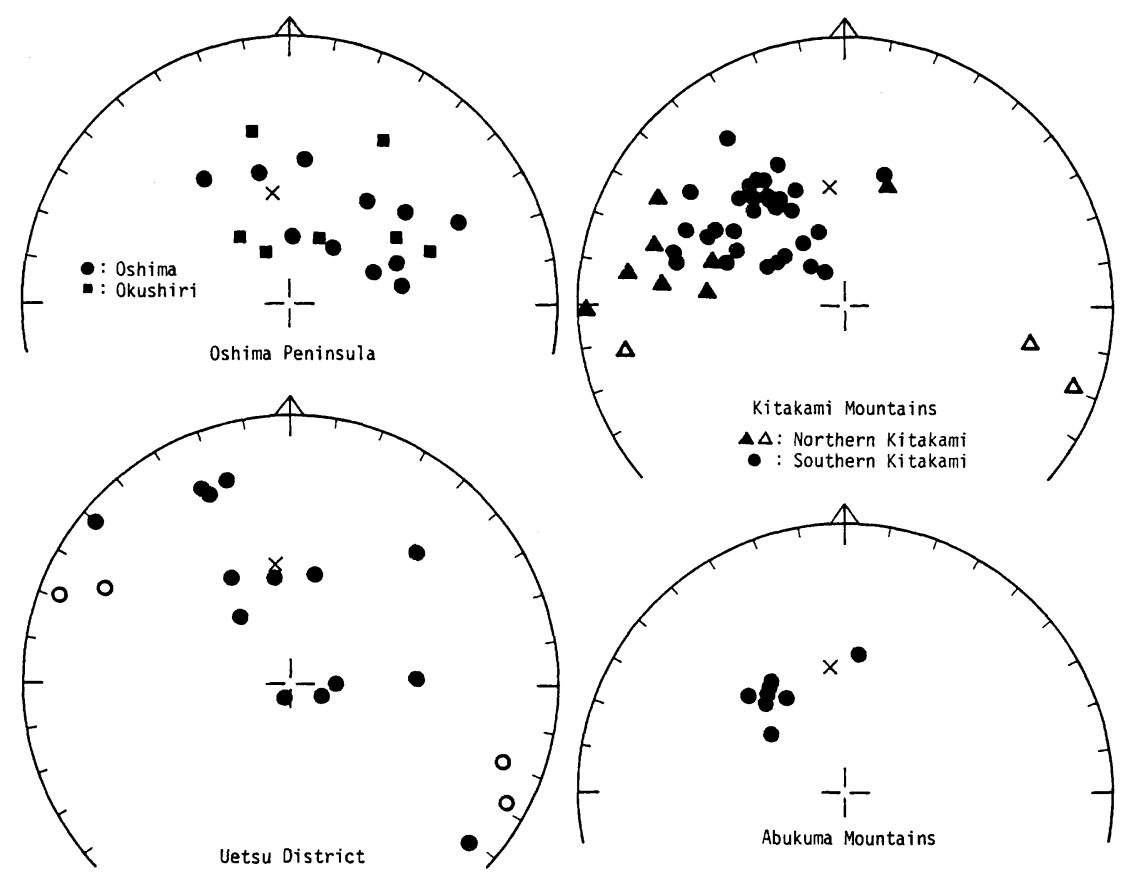

Fig. 1. Site mean directions of the Oshima Peninsula and Okushiri Island, Kitakami mountains, Uetsu Province and Abukuma mountains. Closed symbols indicate to be the lower hemisphere (positive inclination) and open symbols to be the upper hemisphere (negative inclination). Cross mark is the present geomagnetic field direction at sampling area.

(Table 2 and Fig. 1). However, most of the samples measured had positive inclination. The NRM directions from the Uetsu Province were well grouped at each sampling site or within a single body, but between-body directional scatter was remarkable. Therefore, we were unable to estimate the area mean direction for this region. Such an inconsistency in directions between individual granitic bodies may imply that more local tectonic deformations occurred in the Uetsu Province. The Uetsu Province, by the paleomagnetic data, is definitely separated from the Kitakami block. Its boundary is likely to be the volcanic front by SUGIMURA (1960).

\subsection{Kitakami Province}

Granitic rocks from the Kitakami Province were mostly normally magnetized, and the NRM directions were found to be almost northwesterly to westerly (Table 3 and Fig. 1). Only gabbroic rocks taken at Ichinohe were reversely magnetized. The Kitakami region was divided into two parts, northern and southern Kitakami blocks, from the significant differnce in NRM directions (ITO and TOKIEDA, 1980). The area mean direction for the northern Kitakami block was $-81.1^{\circ}$ in declination and $22.3^{\circ}$ in inclination and that for the southern Kitakami block was $-44.4^{\circ}$ and $51.7^{\circ}$, respectively. The area mean of the reversed samples in the northern Kitakami block is $D=105.3^{\circ}, I=-20.0^{\circ}$. Thus the difference in declination between these two blocks is 


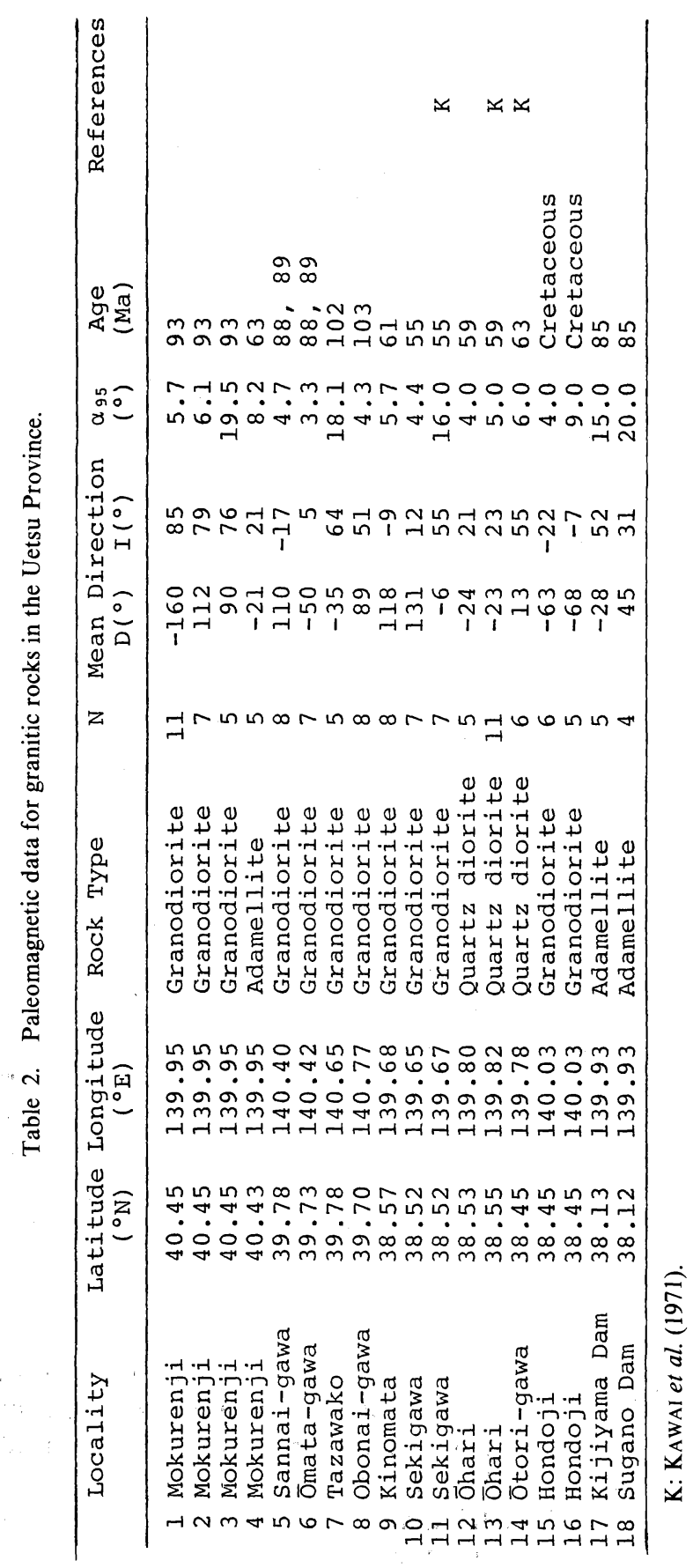


very remarkable and the northwesterly to westerly declinations of the blocks are evidently opposed to the northeasterly ones of the Oshima Peninsula and Okushiri Island of Hokkaido.

\subsection{Abukuma Province}

All samples measured were normally magnetized (Table 4 and Fig. 1), and the area mean direction for this block was $-31.9^{\circ}$ in declination and $54.6^{\circ}$ in inclination. The mean is close to that for the southern Kitakami block, but it is apparently different from the area mean for the Oshima Peninsula and Okushiri Island.

\subsection{Southwest Honshu}

The NRM directions of granitic rocks from Southwest Honshu are well consistent with those of Cretaceous or early Tertiary volcanic and sedimentary rocks reported by many workers (NAGATA et al., 1959; KAWAI et al., 1961; SASAJIMA and SHIMADA, 1966; SASAJIMA et al., 1968; KAWAI et al., 1971; DOMEN, 1971; Kono et al., 1974). Site mean directions of magnetization for normally magnetized rocks were found to be almost northeasterly (Tables 5 and 6 and Fig. 2). Furthermore, there are many reversely magnetized rocks whose NRM directions are nearly antipodal to those of normal samples. The area mean direction of magnetization for the normal samples of the Cretaceous was $50.2^{\circ}$ in declination and $60.5^{\circ}$ in inclination and that for the reversed ones was $-114.8^{\circ}$ and $-55.8^{\circ}$, respectively. The normal samples in the Paleogene have the area mean direction of magnetization of $D=37.6^{\circ}, I=52.3^{\circ}$ and the reversed ones have the mean of $D=-131.4^{\circ}, I=-44.8^{\circ}$, respectively.

\subsection{Northern Kyushu}

Paleomagnetic data for Cretaceous rocks are very scarce in the northern Kyushu region. The Cretaceous granitic rocks collected from this region were normally magnetized, except for one site at Wakinoura (Table 7 and Fig. 2). The magnetic directions of samples taken at Wakinoura were northward and negative inclination. The declinations of the normal samples were northeasterly or easterly. The area mean direction was $75.6^{\circ}$ in declination and $58.1^{\circ}$ in inclination. This mean value is slightly easterly than that for the Cretaceous rocks in Southwest Honshu.

\subsection{South Korea}

All samples of Cretaceous granitic, volcanic and sedimentary rocks taken from South Korea were normally magnetized and site mean directions of magnetization deviated slightly from the present direction of the geomagnetic field at each sampling site, as shown in Table 8 and Fig. 2 (KIENZLE and SCHARON, 1966; ITO and TOKIEDA, 1980; OTOFUJi et al., 1982). The area mean direction of South Korea was $D=16.0^{\circ}$, $I=-57.4^{\circ}$.

\section{Tectonic Movements and Paleomagnetic Pole}

Reports of tectonic rotation deduced from paleomagnetic results have been steadily increasing (e.g., MACDONALD, 1980; WILSON and COX, 1980; OTOFUJ et al., 1981; OTOFuJi and MATSUDA, 1983; ACHACHE et al., 1983; and many others). However, translation and rotational movement about the vertical axis have been 


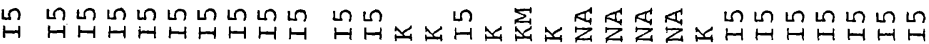

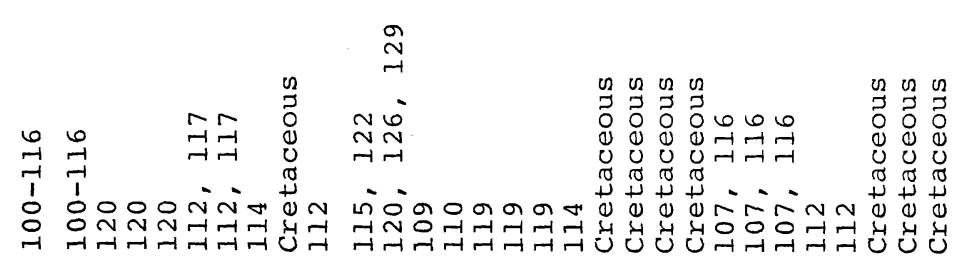

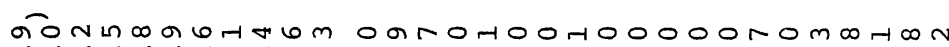
ம

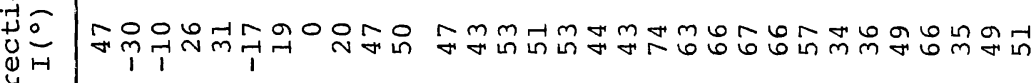
$\rightarrow$

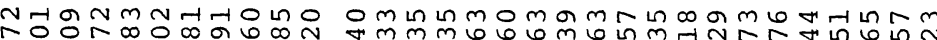
1.

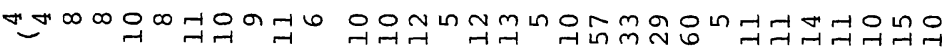

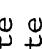

त्र

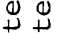

Ð -4

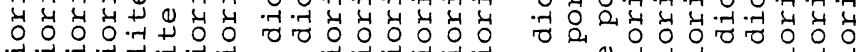

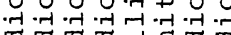
0 ० N N N N N N 年

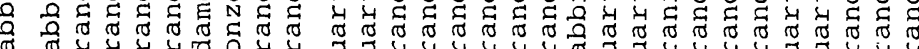

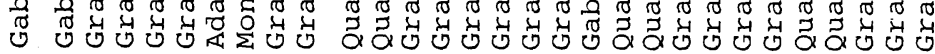

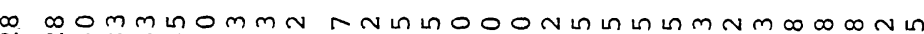
ง

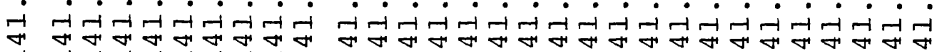

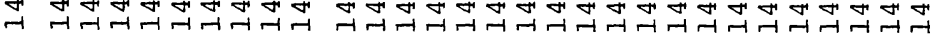

N

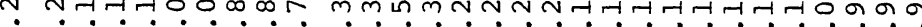

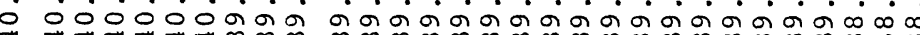
苗 $\mathscr{\sigma}$
$\sigma$
$\sigma$
$\sigma$

\section{$0 \cdot-\cdot{ }^{-1}$}

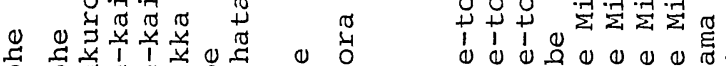

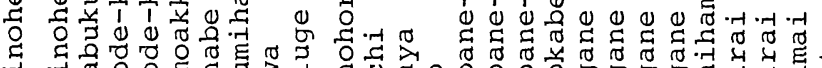
.

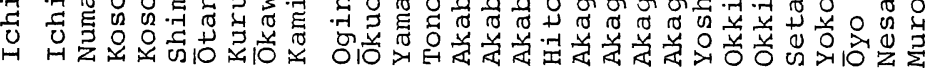
$\rightarrow$ Nm 


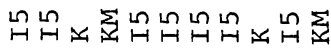

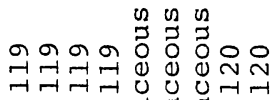

$\cdots \cdots$

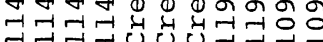

naOomnthomo

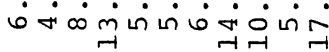

$m m \rightarrow n \infty m \pi n \rightarrow$

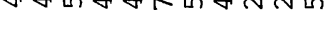

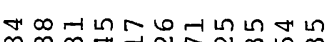

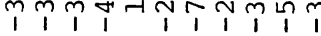

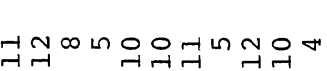

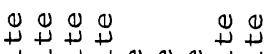

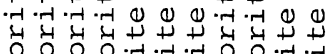

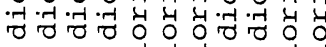
N N N N r

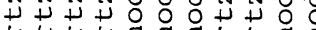
ซ్ర ฉૈ

$\circ m m m \infty \infty 0$ Ln $\operatorname{~nn~}$

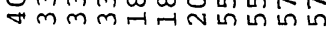

-1-1-1-1

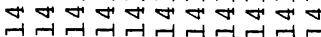

극응ㅇㅇㅇㅇㅇㅇㅇㅛ O $\infty \infty \infty \infty \cdots \infty \sim^{\infty} \infty \infty \infty$

ชี

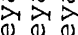

@

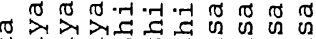

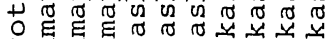

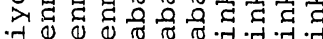

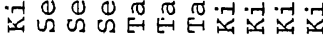

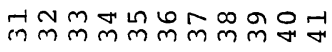

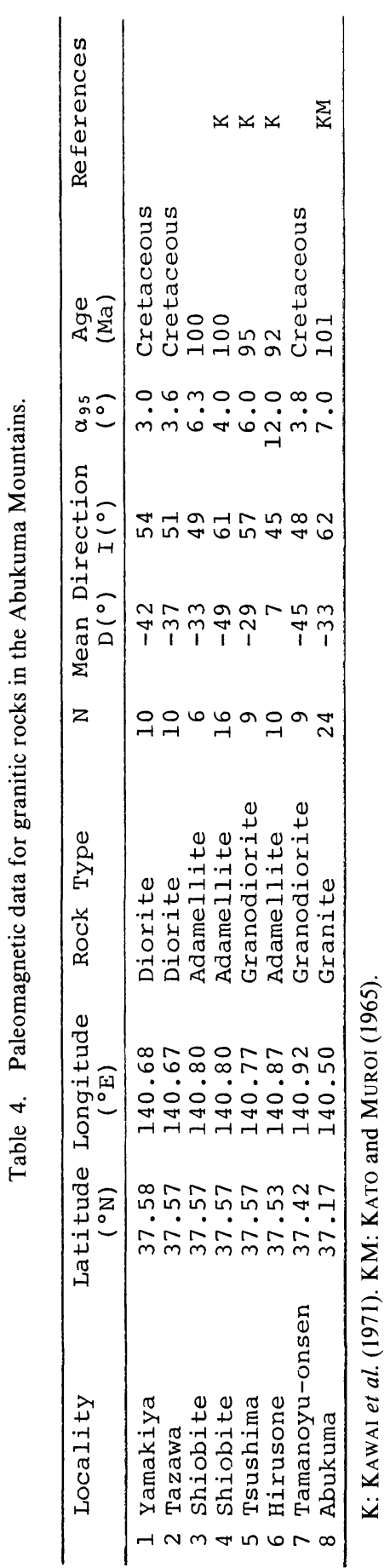




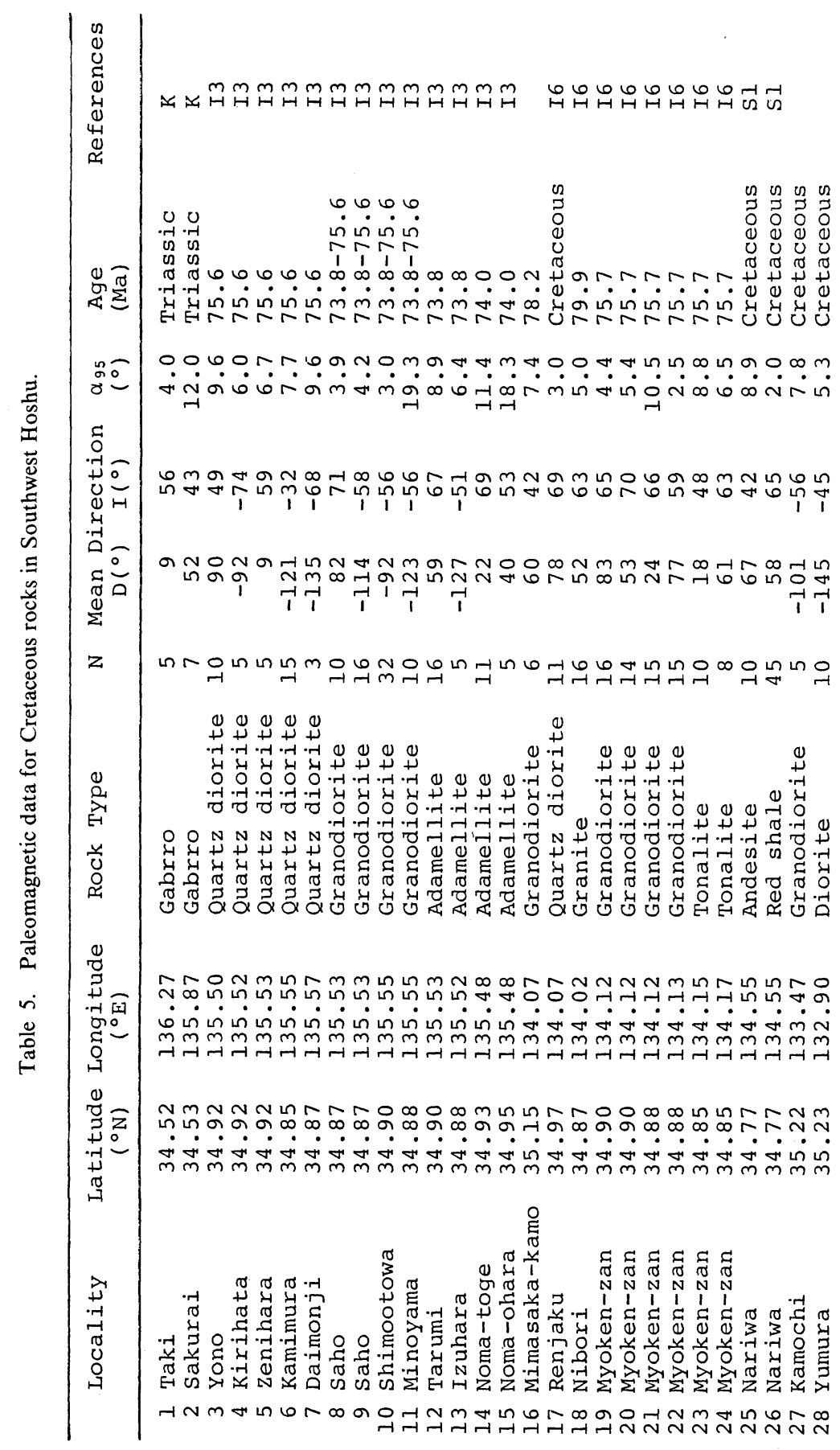




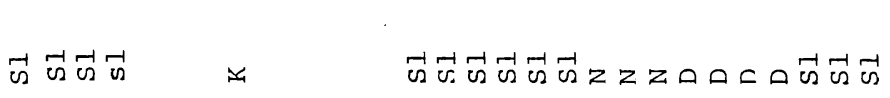

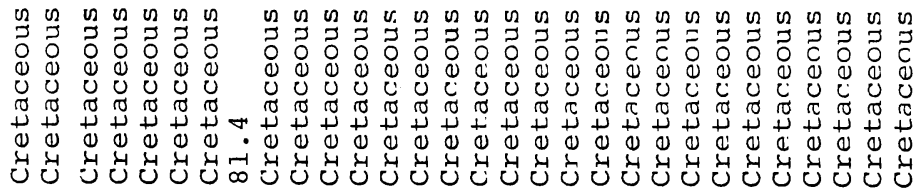

oH

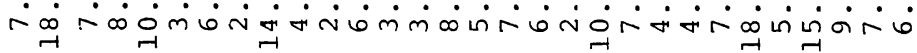

ต

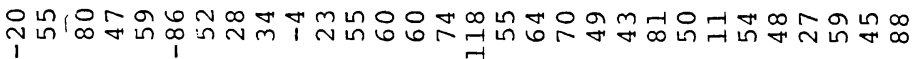

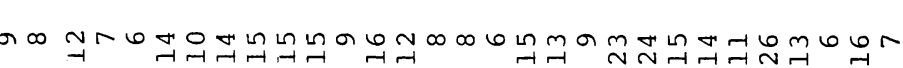

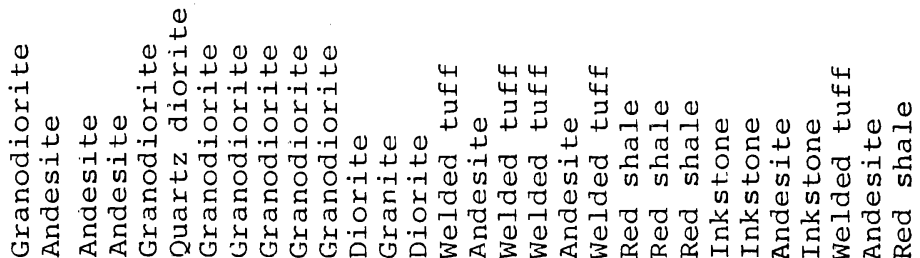

$m \pi$ in

?. N $N$ m $N N N N N$ N

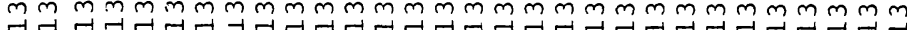

O $\infty m$ 이에

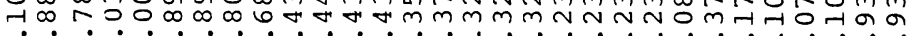
$\dot{m} \dot{m} \dot{m} \dot{m} \dot{m} \dot{m} \dot{m} \dot{m} \dot{m} \dot{m} \dot{m} \dot{m} \dot{m} \dot{m} \dot{m} \dot{m} \dot{m} \dot{m} \dot{m} \dot{m} \dot{m} \dot{m} \dot{m} \dot{m} \dot{m} \dot{m} \dot{m} \dot{m} m \dot{m}$

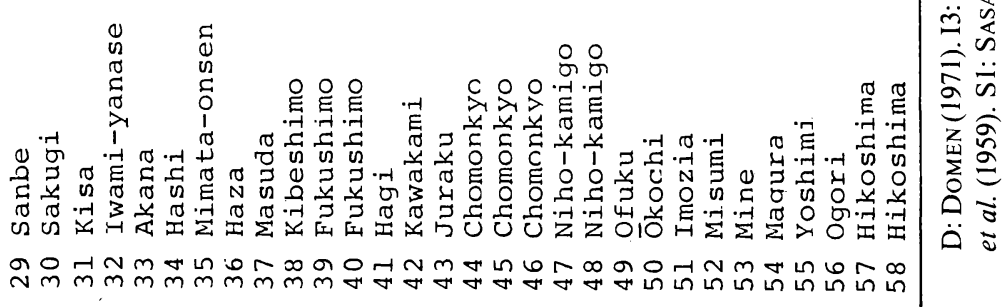




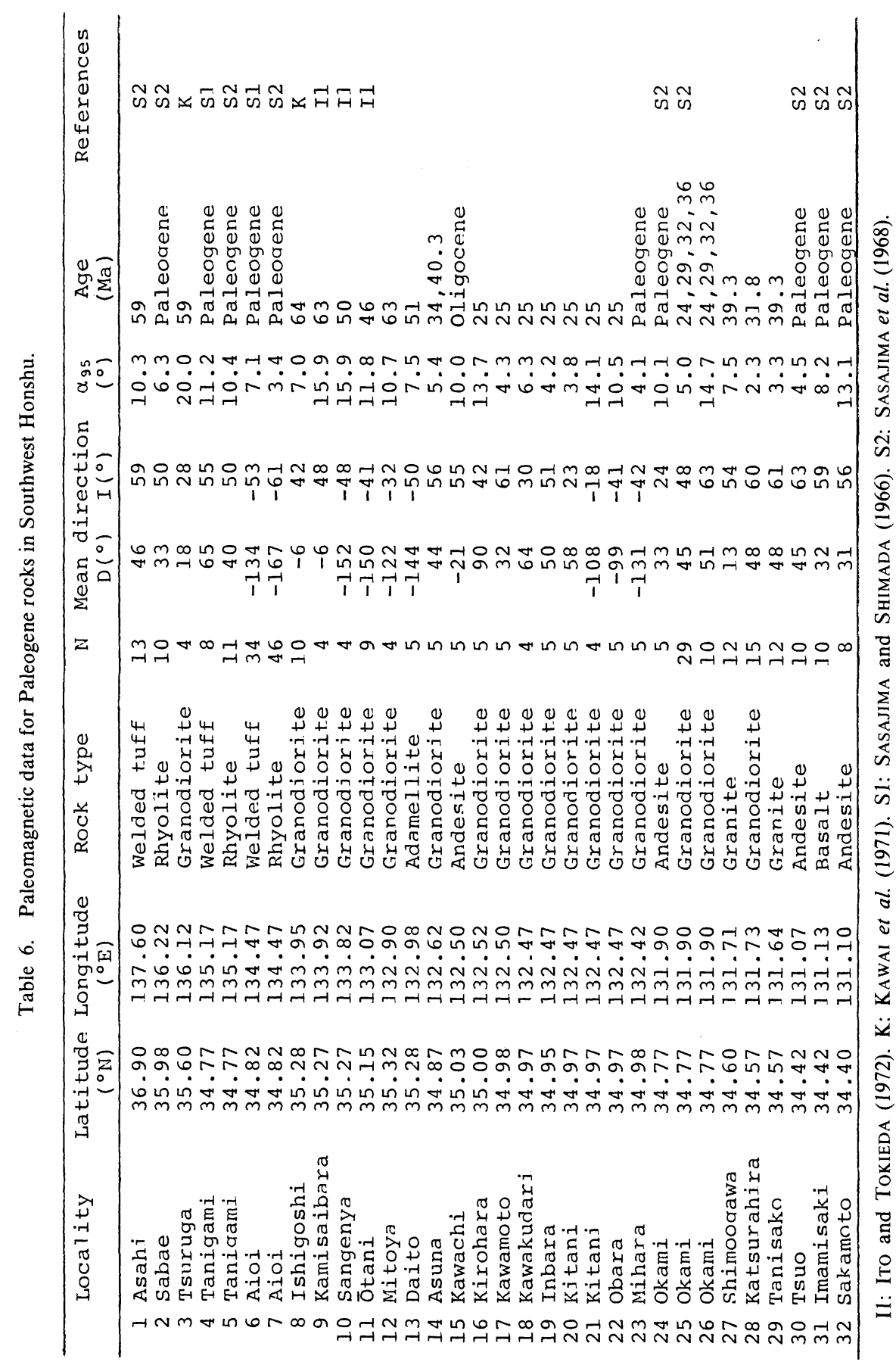




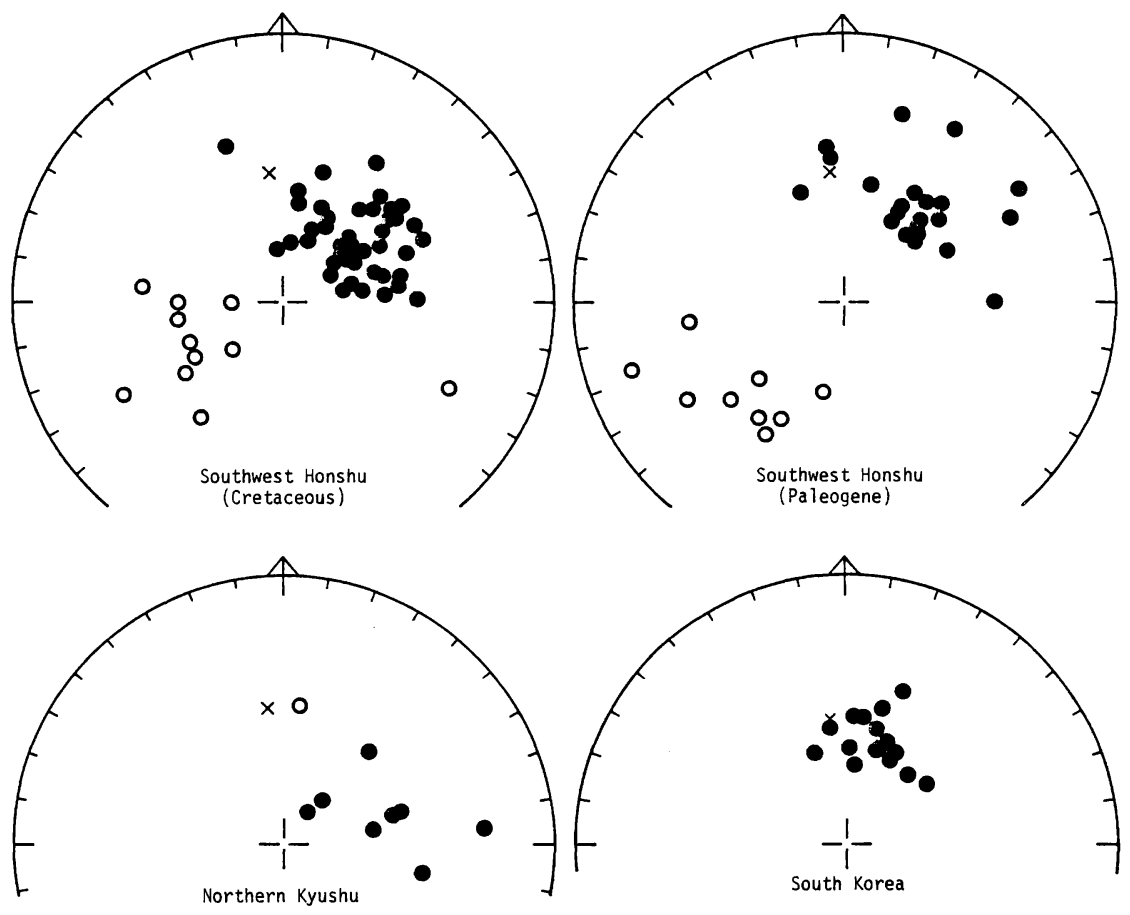

Fig. 2. Site mean directions of Southwest Honshu, northern Kyushu and South Korea. Solid circle indicates to be the lower hemisphere (positive inclination) and open circle to be the upper hemisphere (negative inclination). Cross mark is the present geomagnetic field direction at sampling area.

chiefly discussed in these papers. In general, local tectonic movements are considered to be produced by rotations about inclined axes, but rotation mechanisms about the inclined axes are difficult to relate to the paleomagnetic data. Two rotations about the vertical and horizontal axes are fortunately included, as particular cases, in rotations about the inclined axes. These particular cases are very important to elucidate tectonic movements, so that we consider only the two rotations about the vertical and horizontal axes in order to relate to the paleomagnetic data.

In Fig. 3, $m_{0}$ indicates an original direction of paleomagnetic vector for the normal polarity, and $m_{0}$ indicates that for the reversed polarity. Fig. 3(A) shows that the original directions $m_{0}$ and $m_{0}^{\prime}$ were rotated through angle $\delta$ about the vertical axis $A$ to the present directions $m$ and $m^{\prime}$. In this case, the inclination of remanent vector is unchanged through rotation process, but the declination changes to angle $\delta$. The bending hypothesis of the Japanese Islands by KAWAI et al. (1961) is based on the assumption that original paleomagnetic vectors changed their directions through tectonic rotations about the vertical axes.

On the other hand, rotations about the horizontal axes produce both declination and inclination anomalies in paleomagnetic vectors except and example of $B_{1}$ shown in Fig. 3(B). If original directions $m_{0}$ and $m_{0}^{\prime}$ were rotated through angle $\delta$ about each of the horizontal axes $B_{1}, B_{2}, B_{3}$ and $B_{4}$, or $B_{1}^{\prime}, B_{2}^{\prime}, B_{3}^{\prime}$ and $B_{4}^{\prime}$, then present directions 

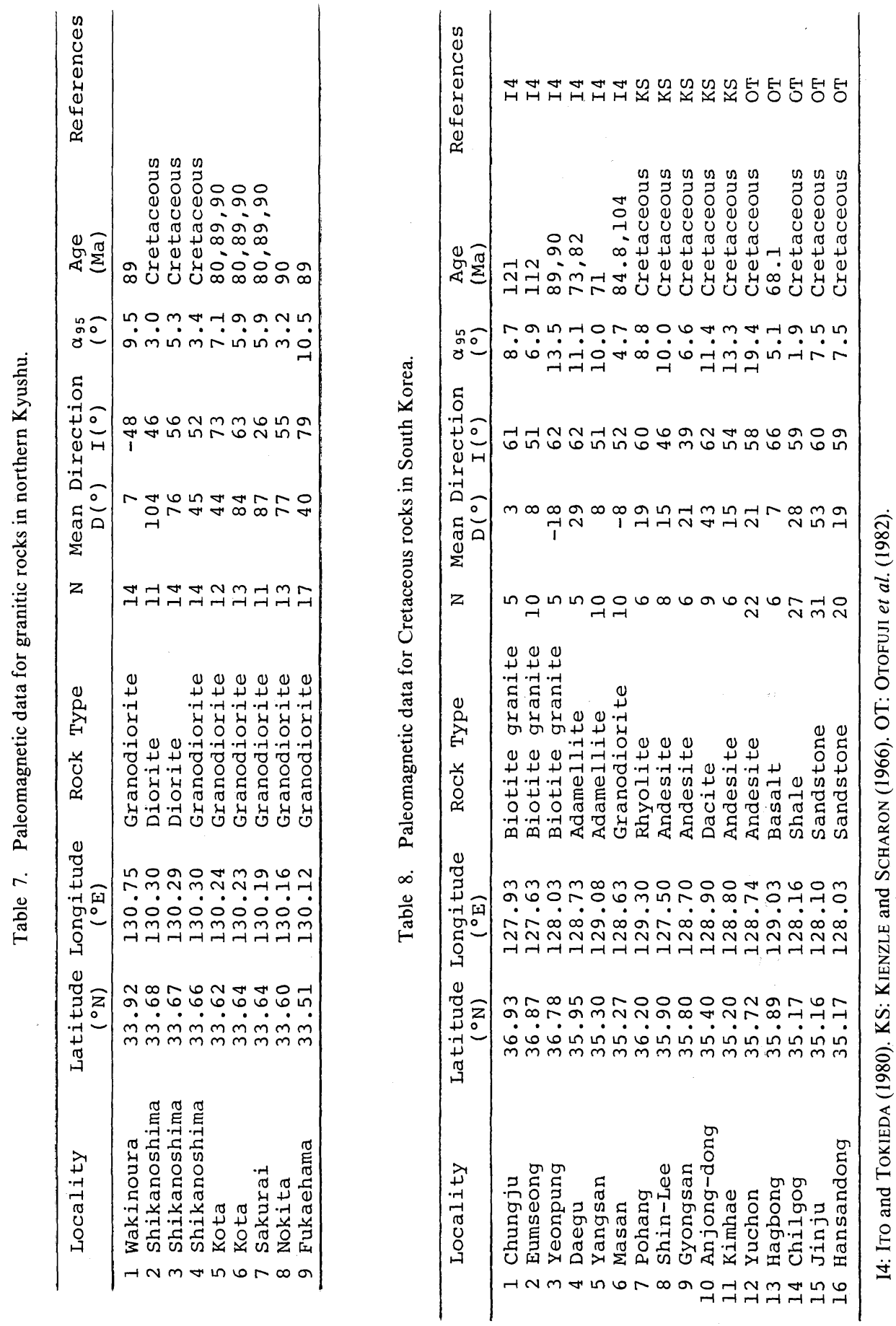


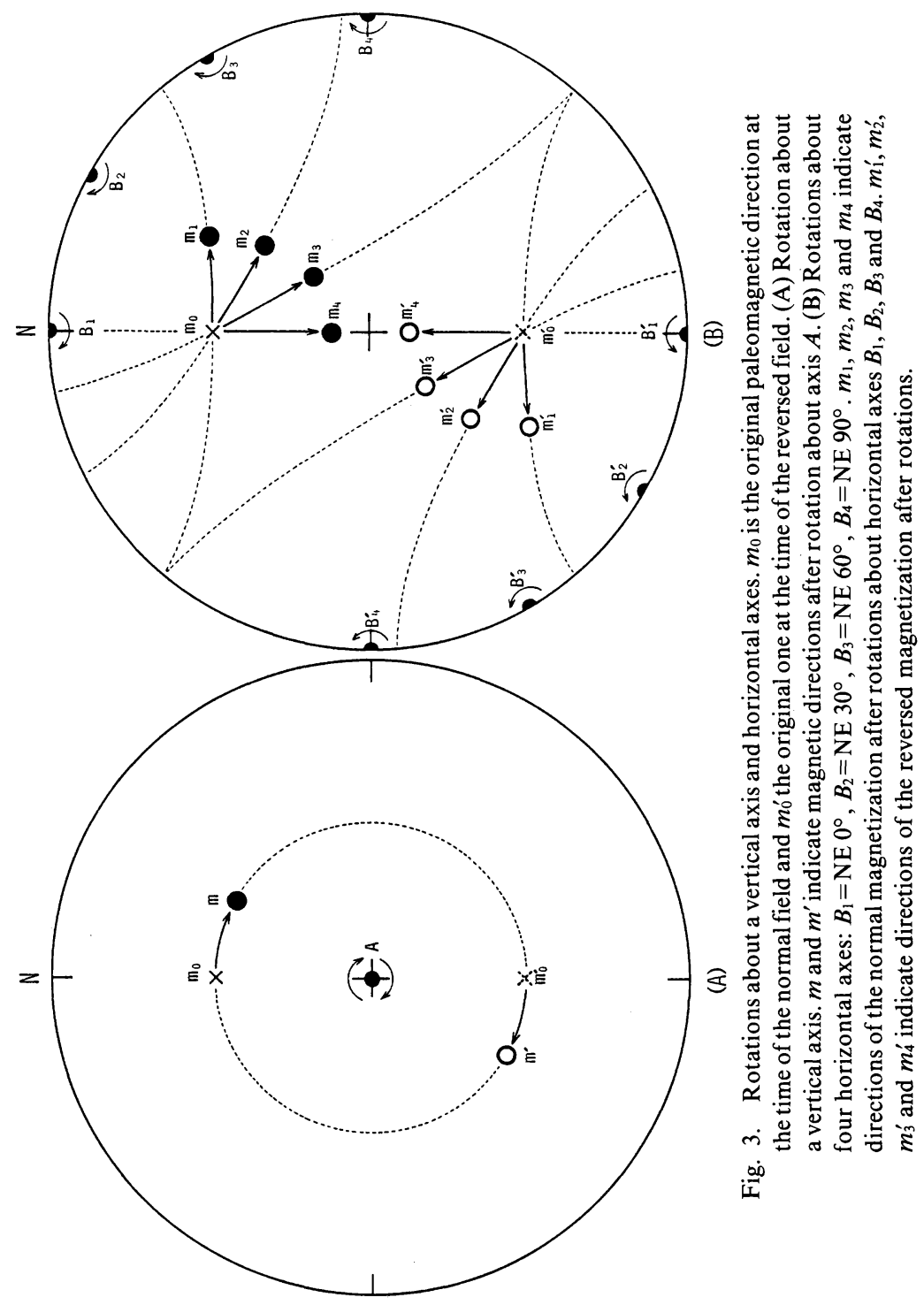


should be indicated by $m_{1}, m_{2}, m_{3}$ and $m_{4}$, or $m_{1}^{\prime}, m_{2}^{\prime}, m_{3}^{\prime}$ and $m_{4}^{\prime}$, respectively. Rotation about a horizonal axis indicates that the paleomagnetic vector moves on a small circle including both the original direction $m_{0}$ and the present direction $m$. The face of the small circle is always perpendicular to the horizontal axis.

It is not so easy to detect an original direction at sampling localities, so that the present geomagnetic field direction is usually used as indicating the original direction. We can find no other way than using the paleomagnetic pole estimated from the paleomagnetic data available for our purpose. If the original direction $m_{0}$ was determined by using the paleomagnetic pole, we can draw a small circle from both the original and present directions and detect an orientation perpendicular to the face of the small circle as the most probable rotational axis in the horizontal.

The Cretaceous paleomagnetic poles from Eurasia have fortunately been calculated by several workers (MCELHINNY, 1973; IRVING, 1977; ACHACHE et al., 1983; TARLING, 1983). Many of the paleomagnetic poles from Eurasia appear to lie in a region near $70^{\circ} \mathrm{N}, 180^{\circ} \mathrm{E}$, and the Cretaceous paleomagnetic poles estimated from North America is also located near the region (HARRISON and LINDH, 1982; TARLING, 1983). In this paper, we would use the paleomagnetic mean pole (lat. $=72.5^{\circ} \mathrm{N}$, long. $=177.5^{\circ} \mathrm{E}$ ) in the upper Cretaceous calculated by ACHACHE et al . (1983) as the Cretaceous paleomagnetic mean pole for Eurasia. This mean pole position for Eurasia is shown in Fig. 4. Virtual geomagnetic poles calculated from the area mean directions of NRM of the Japanese Cretaceous rocks are listed in Table 9 and also shown in Fig. 4. From the figure, it is clear that positions of their virtual poles are inconsistent with each other. It appears, however, that the poles are systematically situated along a great circle. The virtual pole for the South Korea is close to the paleomagnetic mean pole for Eurasia.

\section{Discussion}

Assuming that the geomagnetic pole in the upper Cretaceous had been located at $72.5^{\circ} \mathrm{N}, 177.5^{\circ} \mathrm{E}$ as described previously, the geomagnetic field directions at each sampling locality calculated by using the mean pole position. The geomagnetic field direction at $39.0^{\circ} \mathrm{N}, 141.5^{\circ} \mathrm{E}$ in Northeast Honshu is $D=16.6^{\circ}, I=68.8^{\circ}$, and that at $33.0^{\circ} \mathrm{N}, 133.5^{\circ} \mathrm{E}$ in Southwest Honshu is $D=17.6^{\circ}, I=64.5^{\circ}$, respectively. On the other hand, the present geomagnetic field directions at the same localities in the Northeast and Southwest Honshu blocks are $D=-7.5^{\circ}, I=53.0^{\circ}$ and $D=-6.7^{\circ}$, $I=48.3^{\circ}$, respectively.

In the Uetsu Province, it was impossible to find a significant area mean direction of the NRM for Cretaceous granitic rocks, because the scatter in NRM directions was very remarkable as seen in Fig. 1 and Table 2. However, between-site consistency in directions within a rock body was observed in several granite bodies. The scatter in site mean directions in this region is likely to show that more local and complicated tectonic movements than the southwestern part of Hokkaido or the Kitakami region was substantial. Such local movements are considered to have provided complicated and/or intensive tilting for individual granite bodies. From this unexpected paleomagnetic results of the Uetsu Province, it is thought that Northeast Honshu has not been uniformly bent as a single block relative to Southwest Honshu or the southwestern part of Hokkaido. Therefore, we concluded that Northeast Honshu has 


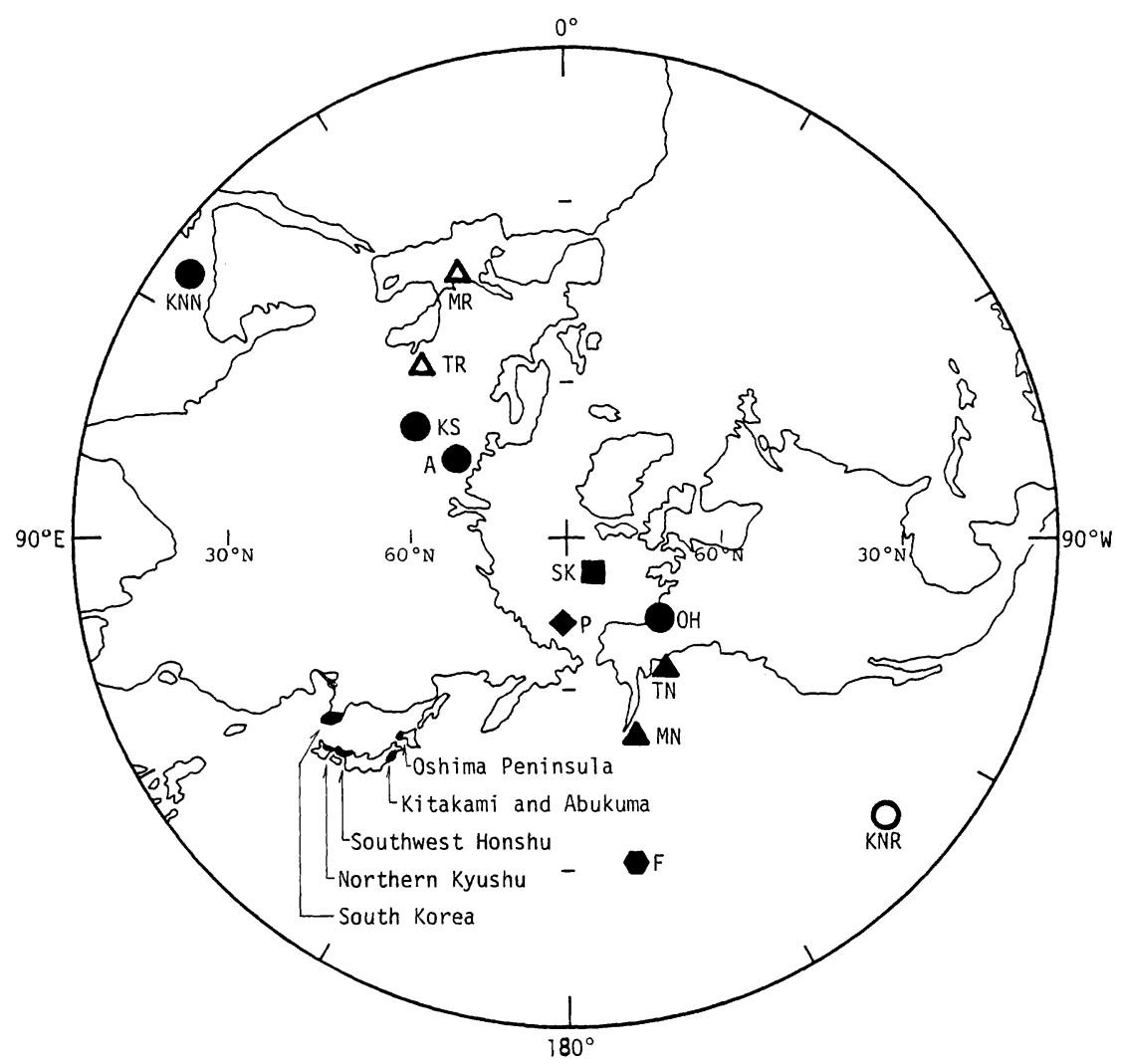

Fig. 4. Virtual geomagnetic pole. Closed symbols indicate north-seeking pole and open symbols southseeking pole. $\mathrm{OH}=$ Oshima Peninsula and Okushiri Island, $\mathrm{KNN}=$ normal sample of northern Kitakami, KNR= reversed sample of northern Kitakami, KS=southern Kitakami, $A=$ Abukuma mountains, $\mathrm{MN}=$ normal sample of Cretaceous rocks in Southwest Honshu, $\mathrm{MR}=$ reversed sample of Cretaceous rocks in Southwest Honshu, $\mathrm{TN}=$ normal sample of Tertiary rocks in Southwest Honshu, $\mathrm{TR}=$ reversed sample of Tertiary rocks in Southwest Honshu, $\mathrm{F}=$ northern Kyushu, SK=South Korea, $\mathrm{P}=$ paleomagnetic mean pole for Eurasia calculated by ACHACHE et al. (1983).

undergone regional tectonic deformations without simple anti-clockwise rotation about the vertical axis. One of their regional deformations is rotation about the horizontal axis, i.e., tilting movement.

The area mean direction of NRM for granitic rocks in the Oshima Peninsula and Okushiri Island of Hokkaido was $30.0^{\circ}$ in declination and $58.4^{\circ}$ in inclination. From this area mean direction, the Oshima and Okushiri region should have been tilted toward the Japan Sea side, and its rotation axis and the amount of rotation are $B_{1}=\mathrm{NW} 34^{\circ}, \delta=18^{\circ}$ as seen in Table 10 . This rotation axis is likely to be parallel to "Old Trench" running through the nearly north-south trend along the west-side of the Hidaka mountains in Hokkaido, which has been expected from the free-air anomaly (TOMODA and SEGAWA, 1971). If tilting had been produced by lateral compression and it was downward, the direction of compressional stress would be perpendicular to 


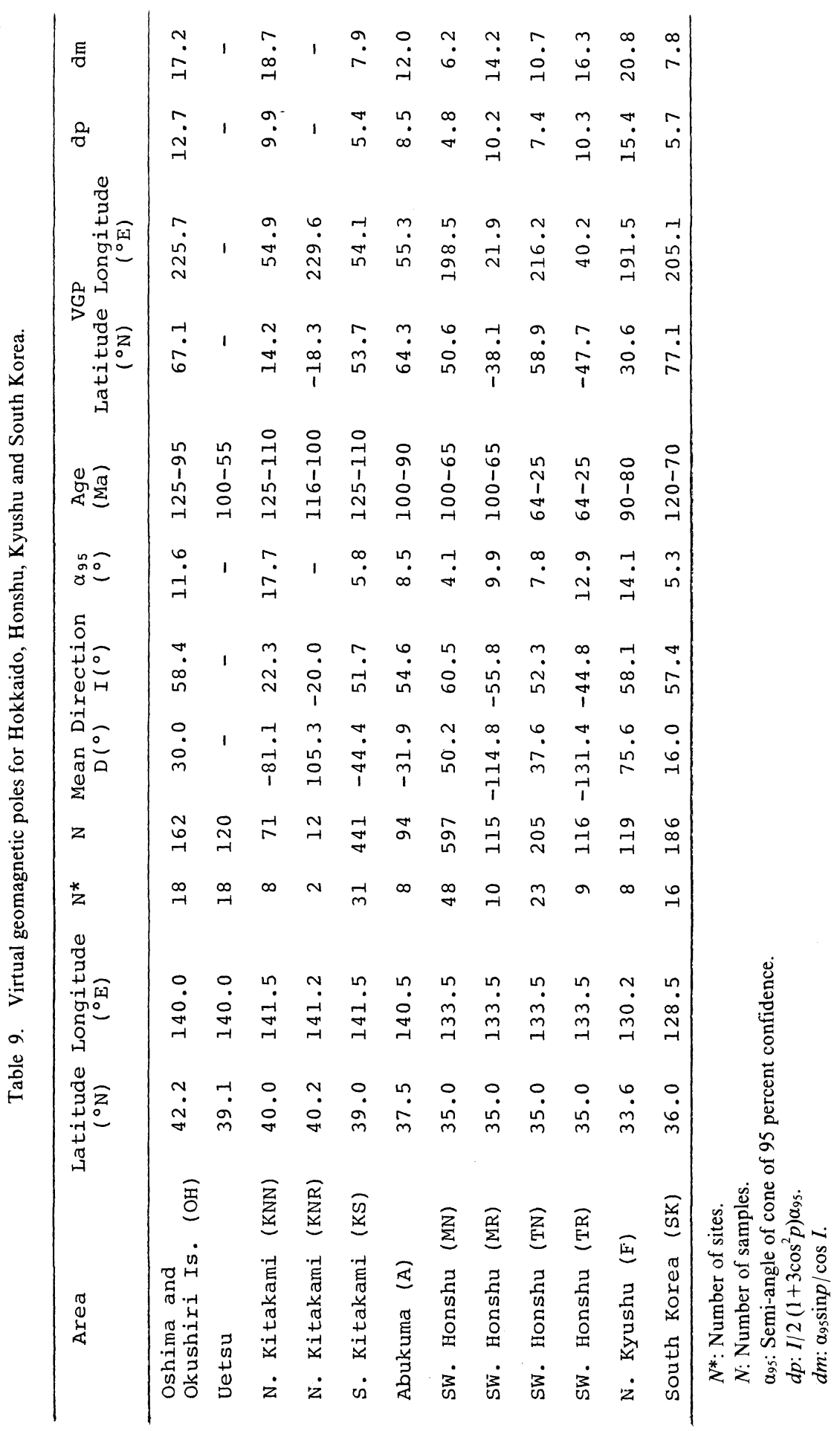


Table 10. Orientations of horizontal axes and rotation angles.

\begin{tabular}{lccccc}
\hline & $\begin{array}{c}\lambda \\
\left({ }^{\circ} \mathrm{N}\right)\end{array}$ & $\begin{array}{c}\lambda_{0} \\
\left({ }^{\circ}\right)\end{array}$ & $\mathrm{B}$ & $\begin{array}{c}\mathrm{H} \\
\left({ }^{\circ}\right)\end{array}$ & $\begin{array}{c}j \\
\left({ }^{\circ}\right)\end{array}$ \\
\hline $\begin{array}{l}\text { Oshima and } \\
\text { Okushiri Is. (OH) }\end{array}$ & 42.2 & 54.8 & $\mathrm{~B}_{1}$ & -34 & 18 \\
N. Kitakami (KNN) & 40.0 & 53.1 & $\mathrm{~B}_{2}$ & -11 & 77 \\
N. Kitakami (KNR) & 40.0 & - & $\mathrm{B}_{2}^{\prime}$ & $(-6)$ & 77 \\
S. Kitakami (KS) & 39.0 & 52.2 & $\mathrm{~B}_{3}$ & 13 & 35 \\
Abukuma (A) & 37.5 & 50.5 & $\mathrm{~B}_{4}$ & 22 & 29 \\
SW. Honshu (MN) & 35.0 & 46.4 & $\mathrm{~B}_{5}$ & 18 & 19 \\
SW. Honshu (MR) & 35.0 & - & $\mathrm{B}_{5}^{\prime}$ & $(24)$ & 26 \\
N. Kyushu (F) & 33.6 & 44.6 & $\mathrm{~B}_{6}$ & 36 & 29 \\
S. Korea (SK) & 36.0 & 46.0 & - & - & - \\
\hline
\end{tabular}

$\lambda$ : Present latitude of sampling locations.

$\lambda_{0}$ : Paleolatitude of sampling locations based on Cretaceous mean pole $\left(72.5^{\circ} \mathrm{N}, 177^{\circ} \mathrm{E}\right)$ for Eurasia (ACHACHE et al., 1983).

$B$ : Horizontal axis.

$H$ : Orientation of horizonal axis.

$\delta$ : Rotation angle.

each rotation axis. If so, stress appears to have acted toward the east from the Japan Sea side in this region.

In case of the Kitakami and Abukuma belts, the area mean directions for the northern Kitakami and southern Kitakami blocks were $D=-81.1^{\circ}, I=22.3^{\circ}$ and $D=-44.4^{\circ}, I=51.7^{\circ}$, respectively, and the area mean for the Abukuma block was $D=-31.9^{\circ}, I=54.6^{\circ}$. The paleomagnetic data indicate that these blocks have tilted toward the Pacific Ocean side. The orientation of rotation axis $B_{2}$ in the northern Kitakami block is NW $11^{\circ}$ and $B_{3}$ in the southern Kitakami block NE $13^{\circ}$ (Table 10). The rotation axis in the northern Kitakami block seems to us to be partially dependent on "Old Trench" by TOMODA and SEGAWA (1971), because the tilting axis is rather parallel to "Old Trench" than the Japan Trench. From the area mean direction for the Abukuma belt, the Abukuma block is thought to have also tilted toward the Pacific Ocean side under circumstances similar to the southern Kitakami block. The orientation of the rotation axis $B_{4}$ is NE $22^{\circ}$ in the horizontal.

The amounts of tilting in the northern Kitakami, southern Kitakami and Abukuma regions are about $77^{\circ}, 35^{\circ}$ and $29^{\circ}$, respectively. It should be noted that the value of the northern Kitakami block is distinctive as compared with two others. This suggests that the northern Kitakami block has undergone more intensive deformations than the southern Kitakami or Abukuma block. The northern Kitakami block may indicate to have been under the influence of "Old Trench". On the contrary, the southern Kitakami and Abukuma blocks are likely to have been affected only by the formation of the Japan Trench. Thus, if tilting deformations have taken place in Northeast Honshu and the southwestern part of Hokkaido, we can assume a tectonic line parallel to the tilting axes, which runs through the nearly north-south trend. This 


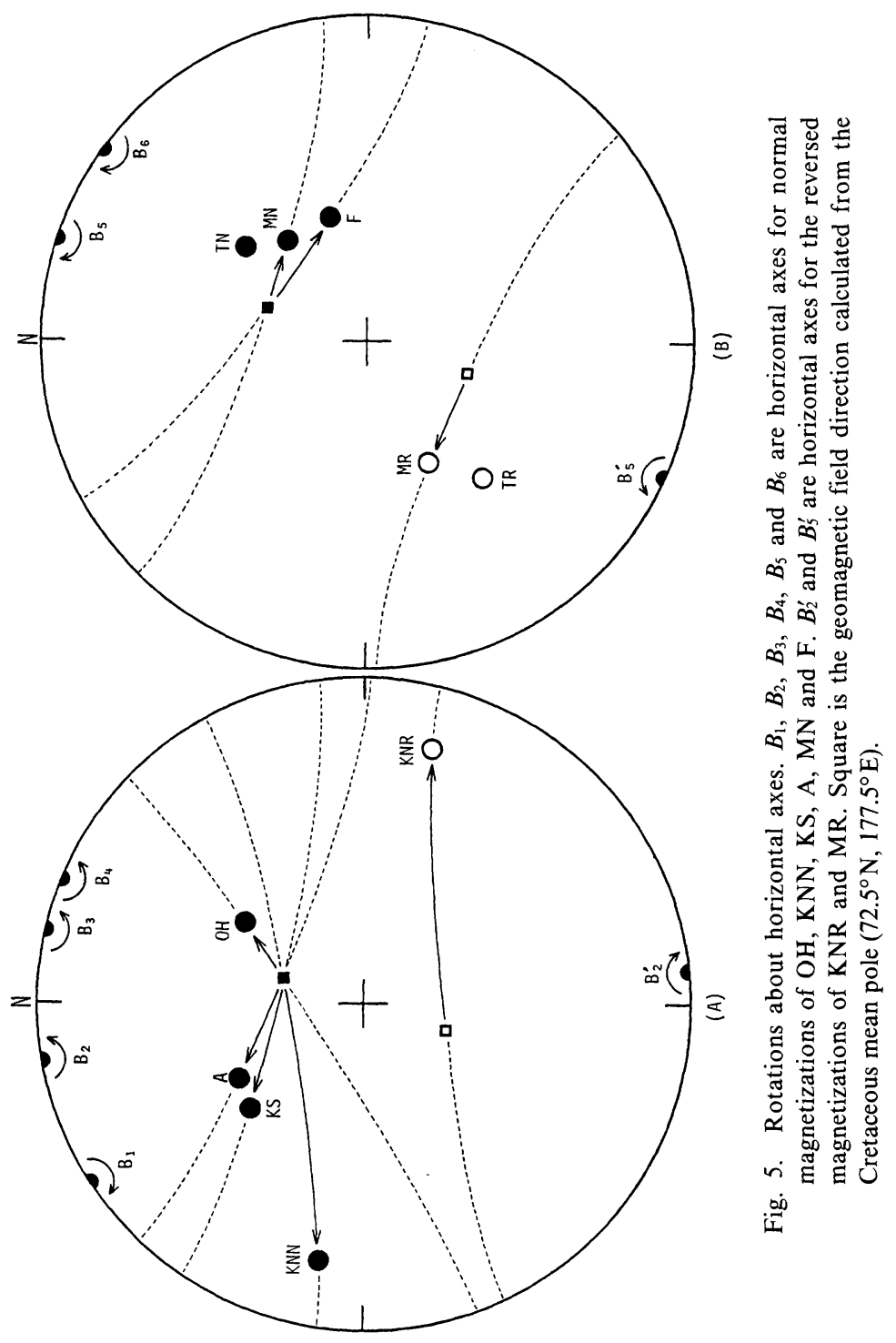




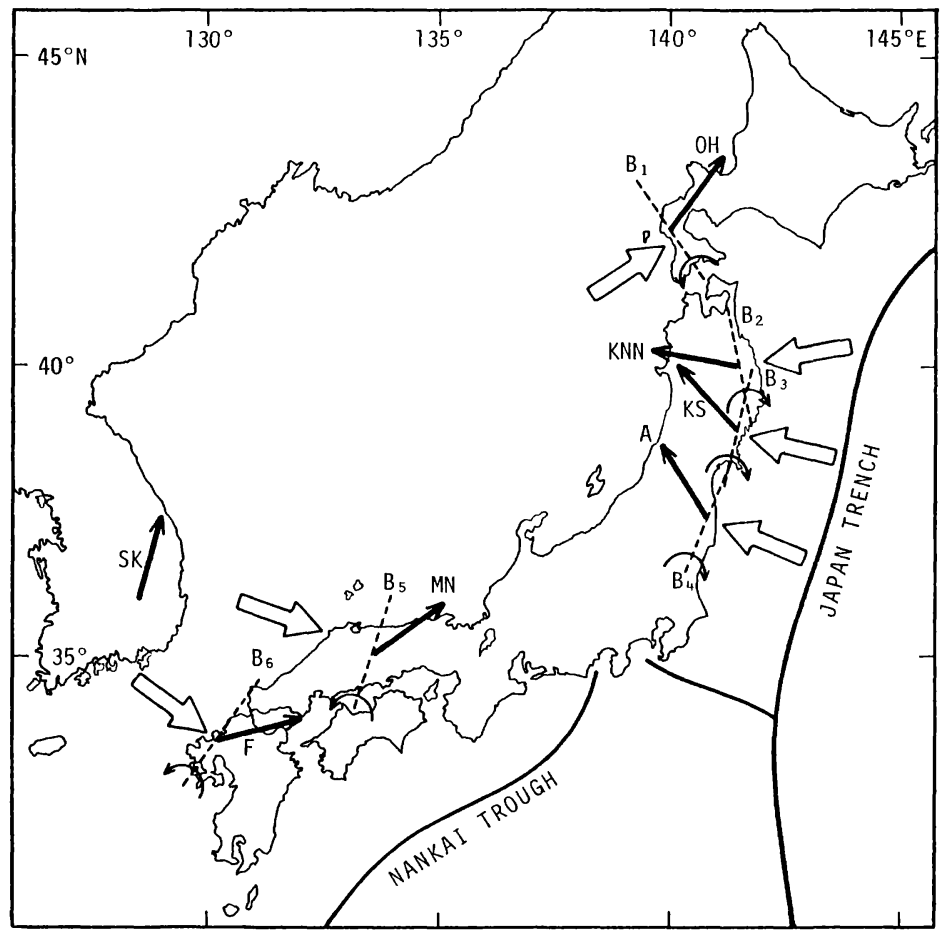

Fig. 6. Directions of horizonal axes and compressional stress. Arrow indicates the area mean direction of NRM and dotted line the direction of horizontal axis. Blank arrow indicates the direction of stress taken perpendicular to the horizontal axis.

hypothetical tectonic line is nearly parallel to the volcanic front of the Quaternary proposed by SUGIMURA (1960).

In Southwest Honshu, the stable directions of NRM represent almost uniform orientation seemingly, as shown in Fig. 2. The existence of many reversed polarities which are approximately antiparallel to the normal ones indicates positively that Southwest Honshu, as a whole, was subjected to substantially similar tectonic deformations. In this case, the rotation axis $B_{5}$ in Southwest Honshu is the orientation of NE $18^{\circ}$ in the horizontal, and $B_{5}^{\prime}$ is SW $24^{\circ}$ (Fig. 5(B)). Southwest Honshu is to have tilted westward as shown in Figs. 5 and 6, and the amount of tilting is estimated to be about $19^{\circ}$ (Table 10). It is unlikely, however, that Southwest Honshu has uniformly tilted westward as a single block. A possibility is that Southwest Honshu had tilted as numerous small blocks which were devided by tectonic lines or faults. It is expected, of course, that there occurred regional vertical movements without rotational deformations in addition to simple tilting deformations of the small blocks.

The paleomagnetic data of the Cretaceous granitic rocks belonging to the Ryoke belt in the Inner Zone of Southwest Japan have been reported by NISHIYAMA et al. (1984). According to their result, the NRM directions of the granitic rocks exposed in the Takanawa Peninsula, Ehime Prefecture, Shikoku, are slightly northeasterly, but the NRM directions are obviously inconsistent with those of the Cretaceous rocks in the Chugoku Province. The difference in NRM directions between the Ryoke belt and 
the northern zone in the Chugoku Province suggests that the southern zone in the Chugoku region has undergone dissimilar tectonic deformations to the northern zone.

The area mean direction for granitic rocks in the northern Kyushu region was $75.6^{\circ}$ in declination and $58.1^{\circ}$ in inclination and it is similar to that of Southwest Honshu. The orientation of the rotation axis $B_{6}$ is taken NE $36^{\circ}$ and the amount of tilting is about $29^{\circ}$ (Table 10). The tilting is westward in the same sense with Southwest Honshu. In these cases, the amount of tilting is simply given by an angle between the reference field and present NRM directions.

The horizontal axes for the individual regions can be drawn as shown in Fig. 6, on the assumption that rotations about the horizontal axes were predominant in the Japanese Islands since the Cretaceous. If such tilting deformations of the Japanese Islands had been produced by lateral compression which may be caused by plate movements, the directions of compressional stress would be perpendicular to each rotation axis. However, there remains a possibility of tilting deformations caused by positive vertical movements (upheaval) of the crust. It is impossible, for the present, to determine whether tilting deformations of the Japanese Islands were produced by lateral compression or by positive vertical movements of the crust.

We thank Dr. Y. Notsu at Department of Physics, Shimane University, for the help in the field and laboratory works throughout this study.

\section{REFERENCES}

Achache, J., V. Courtillot, and J. Besse, Paleomagnetic constraints on the late Cretaceous and Cenozoic tectonics of southeastern Asia, Earth Planet. Sci. Lett., 63, 123-136, 1983.

Birth, T. F. W., Theoretical Petrology, p. 416, John Willey and Sons, 1962.

ClegG, J. A., A. Almond, and P. H. S. Stubbs, Remanent magnetism of some sedimentary rocks in Great Britain, Phil. Mag., 45, 583-598, 1954.

Domen, H., Additional data to the paleomagnetic pole positions for the Cretaceous rocks in Yamaguchi Prefecture, West Japan, Bull. Fac. Edu. Yamaguchi Univ., 20, 21- 23, 1971.

Geological Survey of Korea, Isotope Ages and Geological Map of Korea, 1972.

HARrison, C. G. A. and T. LINDH, A polar wandering curve for North America during the Mesozoic and Cenozoic, J. Geophys. Res., 87, 1903-1920, 1982.

IRVING, E., Drift of the major continental blocks since the Devonian, Nature, 270, 304-309, 1977.

IsHIDA, M., Geology of the Yurappu-Dake District, Quadrangle Series, Scale 1: 50000, Geol. Surv. Japan, p. 64, 1981 (in Japanese with English abstract).

ISHIHARA, S., Lateral variation of magnetic susceptibility of the Japanese granitoids, J. Geol. Soc. Japan, 85, 509-523, 1979.

Ishihara, S., Y. Karakida, and K. Sato, Distribution of the magnetite-series and ilmenite-series granitoids in the northern Kyushu-western Chugoku district-with emphasis on re-evaluation of Kokura-Tagawa fault zone, J. Geol. Soc. Japan, 85, 47-50, 1979. (in Japanese with English abstract).

Ito, H. and K. ToKiedA, Paleomagnetism of some Paleogene granites (I), Mem. Fac. Lit. Sci., Shimane Univ., Nat. Sci., 5, 23-28, 1972.

ITO, H. and K. TOKIEDA, Tilting of Hokkaido Island and Kitakami mountains deduced from the NRM of Cretaceous granites, Rock Mag. Paleogeophys., 2, 54-58, 1974.

ITO, H. and K. TOKIEDA, Paleomagnetism of the Ibaragi granitic complex, Mem. Fac. Sci., Shimane Univ., 12, 33-43, 1978.

ITO, H. and K. TOKIEDA, An interpretation of paleomagnetic results from Cretaceous granites in South Korea, J. Geomag. Geoelectr., 32, 275-284, 1980. 
Ito, H., K. ToKiEdA, and Y. Notsu, A paleomagnetic approach to possible tilting movements of Kitakami mountains and Ohsima Peninsula of Hokkaido, Rock Mag. Paleogeophys., 7, 113-120, 1980.

Ito, H., K. ToKIEDA, and Y. Notsu, Paleomagnetic study of granitic rocks in eastern Chugoku, Southwest Japan, Mem. Nat. Cul. Res. San-in Region, No. 22, 29-39, 1982.

KANAYA, H., Potassium, thorium, uranium and magnetic susceptibility of the Cretaceous granitic rocks in the Kitakami mountains, Geol. Surv. Japan Rept., 251, 91-120, 1974 (in Japanese with English abstract).

KANAYA, H. and S. IsHIHARA, Regional variations of magnetic susceptibility of the granitic rocks in Japan, J. Japan. Assoc. Min. Petr. Econ. Geol., 68, 211-224, 1973 (in Japanese with English abstract).

Katada, M. and H. Kanaya, Potassium, rubidium, strontium, thorium, and uranium of the Cretaceous plutons in the Kitakami mountains, J. Japan. Assoc. Min. Petr. Econ. Geol., 75, 173-185, 1980 (in Japanese with English abstract).

Katada, M., H. Onuki, Y. Kato, S. Kanisawa, C. Ono, and M. Yoshil, Zonal arrangement of the Cretaceous granitic rocks, Kitakami mountainland, J. Japan. Assoc. Min. Petr. Econ. Geol., 65, 230-245, 1971 (in Japanese with English abstract).

Kato, Y. and I. MuroI, Paleomagnetic studies of the Cretaceous granitic rocks in north-eastern Japan, 1965 Ann. Progr. Rept. Rock Mag. Res. Group Japan, 179-187, 1965.

KaWAI, N., H. ITO, and S. KUME, Deformation of the Japanese Islands as inferred from rock magnetism, Geophys. J. R. Astron. Soc., 6, 124-129, 1961.

KawaI, N., S. Kume, and H. ITo, Study on magnetization of the Japanese rocks, J. Geomag. Geoelectr., 13, $150-153,1962$.

KAWAi, N., T. NAKAJIMA, and K. HIROOKA, The evolution of the Island Arc of Japan and the formation of granites in the Circum-Pacific belt, J. Geomag. Geoelectr., 23, 267-293, 1971.

Kawano, Y. and Y. Ueda, K-A dating on the igneous rocks in Japan(I), J. Japan. Assoc. Min. Petr. Econ. Geol., 51, 127-148, 1964 (in Japanese with English abstract).

KAWANO, Y. and Y. UEDA, K-A dating on the igneous rocks in Japan (II)-Granitic rocks in Kitakami massif-J. Japan. Assoc. Min. Petr. Econ. Geol., 53, 143-154, 1965a (in Japanese with English abstract).

KAWANO, Y. and Y. UEDA, K-A dating on the igneous rocks in Japan (III) - Granitic rocks in Abukuma massif-, J. Japan. Assoc. Min. Petr. Econ. Geol., 54, 162-172, 1965b (in Japanese with English abstract).

KAWANO, Y. and Y. UEDA, K-A dating on the igneous rocks in Japan (IV)-Granitic rocks in southwestern Japan-, J. Japan. Assoc. Min. Petr. Econ. Geol., 56, 41-55, 1966a (in Japanese with English abstract)

KAWANO, Y. and Y. UEDA, K-A dating on the igneous rocks in Japan (V)_-Granitic rocks in southwestern Japan-, J. Japan. Assoc. Min. Petr. Econ. Geol., 56, 191-211, 1966b (in Japanese with English abstract).

KAWANO, Y. and Y. UEDA, K-A dating on the igneous rocks in Japan (VI)-Granitic rocks, summary-, Sci. Rept. Tohoku Univ., 3rd Series, 10, 65-76, 1967.

Kienzle, J. and L. SCharon, Paleomagnetic comparison of Cretaceous rocks from South Korea and late Paleozoic and Mesozoic rocks of Japan, J. Geomag. Geoelectr., 18, 413-416, 1966.

Kono, M., M. Ozima, and K. Wadatsumi, Paleomagnetism and K-Ar ages of Himeji volcanics, Rock Mag. Paleogeophys., 2, 45-49, 1974.

LEE, M. S., Geology and metalic mineralization associated with Mesozoic granitic magmatism in South Korea, Mining Geol, , 31, 235-244, 1981.

LEE, Y. J., Granitic rocks from the southern Gyeongsang basin, south-eastern Korea, Part 1, General geology and K-Ar ages of granitic rocks, J. Japan. Assoc. Min. Petr. Econ. Geol., 75, 105-116, 1980 (in Japanese with English abstract).

LEE, Y. J. and Y. UEDA, K-Ar dating on granitic rocks from the Eonyang and Ulsan area, Korea, J. Japan. Assoc. Min. Petr. Econ. Geol., 75, 367-372, 1977 (in Japanese with English abstract).

MacDonald, W. D., Net tectonic rotation, apparent tectonic rotation, and the structural tilt correction in paleomagnetic studies, J. Geophys. Res., 85, 3659-3669, 1980.

McElhinny, M. W., Paleomagnetism and Plate Tectonics, p. 358, Cambridge Univ. Press, 1973.

MuraKami, N., Some problems concerning late Mesozoic to early Tertiary igneous activity on the Inner Side of Southwest Japan, Pacific Geology, 8, 139-151, 1974.

Nagata, T., S. Akimoto, Y. Shimizu, K. Kobayashi, and H. Kuno, Paleomagnetic studies on Tertiary and Cretaceous rocks in Japan, Proc. Japan Acad., 35, 378-383, 1959. 
Nedachi, M., Y. Abe, and H. Ueno, Natural remanent magnetizations of ores and igneous rocks of the Akagane ore deposites, Iwate Prefecture, J. Japan. Assoc. Min. Petr. Econ. Geol., 64, 35-52, 1970 (in Japanese with English abstract).

Nishiyama, Y., A. Tokuyama, and H. Ito, Paleomagnetic study of Cretaceous granitic rocks from the Inner Zone of Ehime Prefecture, Shikoku, Rock Mag. Paleogeophys., 11, 63-67, 1984.

Notsu, Y. and H. ITo, Paleomagnetism of Cretaceous granitic rocks from Okushiri Island, West Hokkaido, Rock Mag. Paleogeophys., 9, 53-55, 1982.

Nozawa, T., Radiometric Age Map in Japan-Granitic Rocks-, Scale 1:2000000, Geol. Surv. Japan, 1975.

Nozawa, T., Felsic plutonism in Japan, Geol. Soc. Am., Mem., 159, 105-122, 1983.

Otofuji, Y. and T. MAtsuda, Paleomagnetic evidence for the clockwise rotation of Southwest Japan, Earth Planet. Sci. Lett., 62, 349-359, 1983.

Otofuji, Y., S. Sasajima, S. Nishimura, A. Dharma, and F. Hehuwat, Paleomagnetic evidence for clockwise rotation of the northern arm of Sulawesi, Indonesia, Earth Planet. Sci. Lett., 54, 272-280, 1981.

Otofuji, Y., J. Y. Oh, T. HiRajima, K. D. Min, and S. Sasajima, Paleomagnetism and age determination of Cretaceous rocks from Gyeongsang basin, Korean Peninsula, Geophysical Monograph Series, Vol. 27, pp. 388-396, 1982.

Raguin, E., Geology of Granite, p. 314, John Wiley and Sons Ltd., 1965.

Sasajima, S. and M. Shimada, Paleomagnetic studies of the Cretaceous volcanic rocks in Southwest Japan, J. Geol. Soc. Japan, 72, 503-514, 1966 (in Japanese with English abstract).

SaSajima, S., J. Nishida, and M. Shimada, Paleomagnetic evidence of a drift of the Japanese Main Island during the Paleogene period, Earth Planet. Sci. Lett., 5, 135-141, 1968.

Sasajima, S., S. Nishimura, K. Hirooka, Y. Otofuji, T. van Leeuven, and F. Hehuwat, Paleomagnetic studies combined with fission-track datings on the western arc of Sulawesi, East Indonesia, Tectonophysics, 64, 163-172, 1979.

Shibata, K. and N. Yamada, K-Ar age of a granodiorite from Okushiri Island, Hokkaido, Bull. Geol. Surv. Japan, 29, 45-47, 1978 (in Japanese).

SugimurA, A., Zonal arrangement of some geophysical and petrologicl features in Japan and its environs, J. Fac. Sci. Univ. Tokyo, Sect. 2, 12, 133-153, 1960.

Tarling, D. H., Paleomagnetism, Principles and Applications in Geology, Geophysics and Archaeology, p. 379, Chapman and Hall, 1983.

Tomoda, Y. and J. SegAwA, Gravity anomalies around the Japanese Islands, Kagaku, 41, 68-74, 1971 (in Japanese).

Tsusue, A., T. Mizuta, M. Watanabe, and K. G. Min, Jurassic and Cretaceous granitic rocks in South Korea, Mining Geol., 31, 261-280, 1981.

Wilson, D. and A. Cox, Paleomagnetic evidence for tectonic rotation of Jurassic plutons in Blue mountains, eastern Oregon, J. Geophys. Res., 85, 3681-3689, 1980.

YASKAWA, K., Drift of Southwest Japan relative to South Korea since late Mesozoic-A paleomagnetic approach to the origin of the Japan Sea, Rock Mag. Paleogeophys., 1, 77-82, 1973.

YASKawa, K., Paleolatitude and relative position of South-West Japan and Korea in the Cretaceous, Geophys. J. R. Astron. Soc., 43, 835-846, 1975. 